OPEN ACCESS

Edited by:

Ronald F. Zernicke,

University of Michigan, United States

Reviewed by:

Richard Kreider,

Texas A\&M University, United States Darren Candow,

University of Regina, Canada

Philip Chilibeck,

University of Saskatchewan, Canada

*Correspondence: Indranil Sinha

isinha@bwh.harvard.edu;

isinha@partners.org

Specialty section:

This article was submitted to

Exercise Physiology,

a section of the journal

Frontiers in Physiology

Received: 30 April 2020

Accepted: 29 June 2020

Published: 23 July 2020

Citation:

Endo $Y$, Nourmahnad $A$ and Sinha I (2020) Optimizing Skeletal

Muscle Anabolic Response

to Resistance Training in Aging.

Front. Physiol. 11:874.

doi: 10.3389/fphys.2020.00874

\section{Optimizing Skeletal Muscle Anabolic Response to Resistance Training in Aging}

\author{
Yori Endo ${ }^{1}$, Atousa Nourmahnad ${ }^{1}$ and Indranil Sinha ${ }^{1,2 *}$ \\ 'Division of Plastic Surgery, Brigham and Women's Hospital, Harvard Medical School, Boston, MA, United States, ${ }^{2}$ Harvard \\ Department of Stem Cell and Regenerative Biology, Harvard Stem Cell Institute, Cambridge, MA, United States
}

Loss of muscle mass and strength with aging, also termed sarcopenia, results in a loss of mobility and independence. Exercise, particularly resistance training, has proven to be beneficial in counteracting the aging-associated loss of skeletal muscle mass and function. However, the anabolic response to exercise in old age is not as robust, with blunted improvements in muscle size, strength, and function in comparison to younger individuals. This review provides an overview of several physiological changes which may contribute to age-related loss of muscle mass and decreased anabolism in response to resistance training in the elderly. Additionally, the following supplemental therapies with potential to synergize with resistance training to increase muscle mass are discussed: nutrition, creatine, anti-inflammatory drugs, testosterone, and growth hormone $(\mathrm{GH})$. Although these interventions hold some promise, further research is necessary to optimize the response to exercise in elderly patients.

Keywords: sarcopenia, resistance training, skeletal muscle hypertrophy, exercise, aging

\section{INTRODUCTION}

The loss of skeletal muscle mass with aging is a well-known phenomenon (Doherty, 2003). Lean muscle mass decreases substantially after the age of 60 (Melton et al., 2000). Severe, aging-associated loss of muscle mass and strength, also termed sarcopenia (Rosenberg, 1989) and dynapenia (Volpi et al., 2004), respectively, have profound consequences that extend beyond simple loss of mobility (Wolfson et al., 1995). Specific diagnostic criteria for sarcopenia continues to evolve (Cruz-Jentoft et al., 2010; Studenski et al., 2014), but it manifests with increased insulin resistance, loss of bone density, and an increase in falls (Dutta and Hadley, 1995; Rantanen et al., 1999). As such, these patients are at an increased risk of all-cause mortality, incident and mobility disabilities, and loss of independence (Angulo et al., 2020). From a public health perspective, the economic burden of caring for sarcopenic patients is tremendous and accounts for nearly $\$ 28.5$ billion per year in expenditures, after adjusting for inflation (Janssen et al., 2004).

Many recent studies suggest that regimented physical activity, including resistance training, can be beneficial in maintaining muscle strength and function in elderly individuals (Pahor et al., 2014; Losa-Reyna et al., 2019; Martínez-Velilla et al., 2019; Rodriguez-Mañas et al., 2019; Yu et al., 2019). However, although physical training is beneficial at any age, the anabolic response to exercise decreases substantially with aging (Welle et al., 1996; Phillips et al., 2017; Lee et al., 2019). This review explores the mechanisms of cellular and molecular adaptations of skeletal muscle to exercise, with a focus on the aging-associated changes that cause hinderance of its anabolic response to exercise. We further evaluate the efficacy of supplements commonly used with physical training to optimize the exercise benefit on skeletal muscle, with the ultimate goal of preventing sarcopenia and associated adverse events. 


\section{SKELETAL MUSCLE AND AGING}

Aging is associated with changes in multiple biological processes and impacts nearly every facet of tissue homeostasis (LópezOtín et al., 2013). Changes specific to skeletal muscle include diminished fiber number and cross-sectional area (Lexell et al., 1988), a decline in fast-twitch muscle-fibers (Lexell, 1995), and increased fat infiltration (Marcus et al., 2010). These structural changes are responsible for the loss of strength that accompanies muscle aging (Thompson, 2002; Distefano and Goodpaster, 2018). A complex network of signaling factors are precisely regulated to maintain myogenesis and muscle mass. Protein metabolism is regulated by Akt and mammalian target of rapamycin (mTOR) signaling pathways, which are, in turn, activated by various anabolic stimuli to bring about hypertrophic response in skeletal muscle. The induction of the insulin-like growth factor (IGF) pathway, upstream of Akt/mTOR prevents muscle atrophy (Yoon, 2017), highlighting its importance in the maintenance of muscle mass. The circulating levels of IGF1 and IGF-1 binding proteins are decreased in aging, with a corollary reduction in mTOR activation in sarcopenic individuals (Pallafacchina et al., 2002; Léger et al., 2008; Deane et al., 2013; Sharples et al., 2013).

The maintenance of muscle mass may be further limited by diminished nutritional stimuli due to poor nutritional intake (Buford et al., 2010). A lack of nutrients, including essential amino acids (EAAs), is further paired with improper postprandial nutrient handling in the elderly (Wall et al., 2015). These changes contribute to an inability to increase muscle protein synthesis in response to exercise or nutritional availability and results in muscle atrophy with aging (Wilkinson et al., 2018). The inability to properly utilize nutrition is synonymous with anabolic resistance, in which skeletal muscle in old age cannot gain mass despite appropriate cues. Two major factors contributing to this phenomenon in elderly subjects are poor nutrition and a reduction in regimented physical activity (Steffl et al., 2017; Wilkinson et al., 2018).

Muscle hypertrophy can also be negatively regulated by catabolic signals, most prominent of which are the transforming growth factor (TGF) $-\beta$ superfamily and related cytokines. Myostatin and TGF- $\beta$ both limit muscle hypertrophy by regulating the expression of genes involved in differentiation and proliferation in muscle stem cells (Langley et al., 2002; Yang et al., 2007), increasing protein degradation (Sartori et al., 2009), and inhibiting mTOR activation by anabolic stimuli in mature myofibers (Trendelenburg et al., 2009). While their role in sarcopenia remains unclear, some studies have shown that an age-related increase in TGF- $\beta$ signaling from myofibers occurs in parallel with a decline in Notch signaling in satellite cells (Conboy et al., 2003; Chakkalakal et al., 2012), thus resulting in a reduced regenerative capacity of aged muscle. Myostatin was found to be increased in type II muscle fibers (Shibaguchi et al., 2018), suggesting that myostatin may play a role in selective type II fiber atrophy as seen in old age.

Androgenic depravation may be a factor contributing to sarcopenia in old males (Katznelson et al., 1996; Kenny et al., 2001; Ly et al., 2001). Testosterone promotes skeletal muscle hypertrophy directly by increasing protein synthesis (Ferrando et al., 1998) and muscle stem cell division (Powers and Florini, 1975), and indirectly by increasing IGF-1 expression via ERK and mTOR signaling (Sculthorpe et al., 2012). The exact role of testosterone in sarcopenia remains to be established; however, a study reported a significant association between serum-free testosterone and muscle mass in well-nourished, elderly men (Baumgartner et al., 1999). A corollary study demonstrated that lower circulating testosterone was associated with decreased maximal performance capacity in elderly men (Häkkinen and Pakarinen, 1993).

Chronic inflammation, as occurs with aging, has been shown to have detrimental effects on muscle physiology. In particular, the NF- $\mathrm{kB}$ pathway may be causative in limiting skeletal muscle repair following injury and hastening atrophy (Li et al., 2008). NF-KB is highly expressed in elderly people with muscle wasting (Bruunsgaard and Pedersen, 2003) and its level correlates with decreased anabolic response (Cuthbertson et al., 2005). In multiple preclinical models, NF- $\kappa B$ limited myoblast differentiation and regeneration following injury (Oh et al., 2016). Taken together, the evidence suggests that pharmacological inhibition of chronically activated NF- $\mathrm{BB}$ may limit aging-associated muscle loss. Indeed, non-steroidal antiinflammatory drugs (NSAID)s promote muscle regeneration following injury, although its benefit in limiting sarcopenia remains to be elucidated (Thaloor et al., 1999; Oh et al., 2016).

In addition to alterations in the systemic milieu, intrinsic changes within myofibers and muscle stem cells with aging also affects the ability of skeletal muscle to respond to anabolic stimuli. Hyperphosphorylation of mTORC1, which impairs its activation (Kang et al., 2013), is found in aged muscle of human (Markofski et al., 2015). Therefore, defective mTOR signaling likely underlies the resistance of skeletal muscle to anabolic stimuli (Guillet et al., 2004), insulin resistance (Rasmussen et al., 2006), and impaired protein/glucose homeostasis in aged skeletal muscle (Petersen et al., 2015). Mitochondrial dysfunction has also been associated with sarcopenia (Coen et al., 2013) and mitochondrial DNA damage has been shown to cause muscle wasting (Amara et al., 2007). While there are no pharmacotherapeutics that are efficacious in attenuating skeletal muscle loss in aging, resistance training may limit some of these pathologic aging associated changes in skeletal muscle by augmenting mTOR activity (Song et al., 2017).

\section{EFFECT OF RESISTANCE EXERCISE TRAINING ON SKELETAL MUSCLE}

Physical activity, especially resistance training, is unequivocally beneficial for elderly patients with regards to enhancing muscle mass and strength (Fiatarone et al., 1990; Dibble et al., 2006; Peterson et al., 2011; Drummond et al., 2012). A recent review found that when progressive resistance training (PRT) is performed 2-3 times a week at a high intensity, it results in improved physical function and strength (Liu and Latham, 2009). The frequency and duration of resistance exercise in elderly are recommended at 2-4 times per week on alternating days and 
lasting 30-60 min each; $1-3$ sets of $8-15$ reps at $80 \%$ of onerep maximum strength, with a monthly progressive adjustment (American College of Sports Medicine Position Stand, 1998; Law et al., 2016). In skeletal muscle, functional overload induces hypertrophy resulting in increased muscle mass and fiber size in a dose-dependent manner (Frontera et al., 1988). Previous studies have demonstrated that resistance exercise or muscle contraction increases overall muscle protein turnover in favor of protein synthesis through the activation of the mTOR pathway (Biolo et al., 1995). In addition to its direct anabolic effect, exercise has been shown to increase the circulating levels of IGF-1 (Borst et al., 2001) and androgens (Hawkins et al., 2008), while decreasing myostatin levels (Hittel et al., 2010). Furthermore, physical activity promotes restoration of insulin sensitivity, mitochondrial biogenesis, and reduces inflammation (Nieman et al., 2003; Campbell and Turner, 2018).

\section{ATTENUATED EXERCISE BENEFIT IN THE ELDERLY ON MUSCLE MASS AND STRENGTH}

Despite the consensus that regimented physical training is beneficial for the maintenance of strength and function, numerous studies suggest that the effects of exercise on skeletal muscle physiology decreases with aging. Anabolic resistance describes the inability of the body to add muscle mass despite physical activity (Kumar et al., 2009; Rivas et al., 2012; Francaux et al., 2016). In older patients, the increase in lean muscle mass following resistance exercise training is substantially less than younger subjects (Pedersen et al., 2003). As such, the gain in strength following regimented exercise programs are substantially less in the elderly (Welle et al., 1996; Kosek et al., 2006; Booth and Laye, 2010). Diminished induction of muscle regeneration following exercise further dampens the overall hypertrophic response in the elderly (Ogawa et al., 1992; Behnke et al., 2012; Suetta et al., 2013). In addition, elderly patients suffer from impaired muscle activation secondary to aging-associated changes in motor unit density and morphology (Campbell et al., 1973; Raj et al., 2010; Hepple and Rice, 2016). Resistance exercise training improves innervation and thus muscle strength in elderly even without fiber hypertrophy (Messi et al., 2016). Despite exercise, however, the numbers of motor units may still decline with aging (Power et al., 2012; Piasecki et al., 2016), limiting the functional improvement attainable from exercise. Understanding the limitations of resistance training and potential mechanisms underlying this phenomenon is critical for improving exercise benefit in the elderly population.

\section{OPTIMIZING SKELETAL MUSCLE RESPONSE TO EXERCISE IN AGING}

\section{Nutritional Supplementation}

The acute anabolic responses to feeding and exercise were found to be dampened in old subjects compared to their young counterparts, thus limiting their recovery, and muscle growth (Cuthbertson et al., 2005; Durham et al., 2010). It has been hypothesized that the blunted increase in protein synthesis following acute muscle loading may influence the smaller gains in lean tissue following resistance exercise training in older adults (Durham et al., 2010). As such, supplementation of highquality protein may improve anabolic response to a single bout of exercise (Drummond et al., 2008; Dideriksen et al., 2011; Pennings et al., 2011). Whole protein supplements such as whey and casein, both milk-derivatives, are popularly ingested with the intention to increase muscle mass. Casein, when used as a pre-sleep protein supplement, has been shown to increase myofibrillar protein synthesis rates overnight in older adults (Kouw et al., 2017). When combined with a bout of resistance exercise in the evening, rates of protein synthesis were even higher (Holwerda et al., 2016). While fiber hypertrophy was seen with pre-sleep protein ingestion during a resistance training regimen in young men (Snijders et al., 2015), outcomes in older individuals require further investigation (Holwerda et al., 2016).

Specific amino acid supplements are also available, in the forms of EAAs, branched-chain amino acids (BCAAs), and leucine. Leucine-rich EAA supplementation enhanced muscle strength following exercise, although the study included elderly women only (Kim et al., 2012). It is important to note, however, that prolonged protein supplementation with whey or casein, in the setting of a training program, does not appear to improve the exercise response in elderly patients (Godard et al., 2002; Kukuljan et al., 2009; Verdijk et al., 2009). $\beta$-hydroxy- $\beta$ methylbutyrate (HMB), a metabolite of leucine which directly activates mTOR, has also been investigated and increased lean muscle mass and strength in sarcopenic individuals (Oktaviana et al., 2019). In total, protein and amino acids are a promising exercise supplement for the elderly. Current recommendations for daily protein intake in most older individuals are 1.21.5 grams protein/kilogram body weight (Duetz et al., 2014). Interventional trials are required to identify the appropriate composition of proteins and/or amino acids, as well as the timing of delivery.

Separately, creatine is essential for muscle ATP production and has been commonly ingested to enhance anabolic response to exercise. Multiple studies have presented some evidence that creatine treatment, in combination with resistance training, enhances gains in muscle mass and strength following exercise beyond what is attainable with resistance exercise alone (Candow et al., 2019). The benefit of creatine therapy alone without resistance training remains unclear; some have suggested that creatine ingestion improves lean muscle mass in the elderly (Gotshalk et al., 2002), whereas others have observed no benefit in muscle mass or strength with creatine administration (Lobo et al., 2015; Baker et al., 2016; Chami and Candow, 2019). However, in elderly subjects, supplementing resistance training with creatine increased lean muscle mass and strength when compared to placebo (Candow et al., 2014; Devries and Phillips, 2014; Chilibeck et al., 2017). In addition to its known role in ATP production, numerous studies suggest that creatine's positive effect on aging muscle may work through several mechanisms, including by inducing proteins downstream of the mTOR 
pathway (Safdar et al., 2008), decreasing protein degradation (Parise et al., 2001), and functioning as an antioxidant (Sestili et al., 2011). Importantly, creatine therapy appears to have a low risk profile with minimal adverse effects (Kreider et al., 2017), making it an attractive supplement.

Other recently proposed nutritional supplements to counter sarcopenia and dynapenia include vitamin D and omega-3 polyunsaturated fatty acids. Vitamin D is diminished by up to 4 fold in older adults (MacLaughlin and Holick, 1985). Low vitamin D levels have been linked to muscle atrophy (Visser et al., 2003). Several studies found that vitamin D3 supplementation in the elderly results in increased muscle strength (MoreiraPfrimer et al., 2009) as well as reduction in falls and fractures when combined with calcium (Pfeifer et al., 2009). However, others have reported no improvement in functional capacity with vitamin D supplementation (Uusi et al., 2015; Levis and GómezMarín, 2017; Shea et al., 2019). Omega-3, commonly found in fatty fish and seafood, may also limit sarcopenia progression and improve protein synthesis in response to anabolic stimuli (Smith et al., 2011). In addition, multiple studies show that omega-3 augments the effects of resistance training and further increases muscle mass and strength in older adults (Rodacki et al., 2012; Da Boit et al., 2017). Further interventional studies will be required to better define the efficacy and dosage for these compounds, but both are potentially efficacious supplements.

Multi-ingredient protein (MIP)-based supplements may prove to be more efficacious in improving muscle mass and strength gains with exercise as compared to single nutritional supplements alone. In a clinical trial, a MIP supplement consisting of whey protein, creatine, calcium, vitamin D, eicosapentaenoic acid, and docosahexanoic acid improved both lean muscle mass and strength in elderly patients, during exercise, as compared to placebo (Bell et al., 2017; O'Bryan et al., 2020). However, within a metanalysis, there was no benefit in muscle strength and mass, as compared to protein supplementation alone, in response to exercise (O'Bryan et al., 2020). This highlights that future research must focus on defining specific combinations and dosages.

\section{NSAID Therapy}

Chronic, age-related inflammation in skeletal muscle may play a role in aging-associated muscle loss (Barnes and Karin, 1997). As mentioned previously, NF- $\mathrm{kB}$, a master transcriptional regulator of inflammation, becomes upregulated in skeletal muscle with aging (Hayden and Ghosh, 2004). This has led to investigations of whether NF- $\kappa \mathrm{B}$ inhibition using commercially available NSAIDs can improve the maintenance of muscle mass (Yamamoto and Gaynor, 2001). Inhibition of NF-кB directly improves muscle regeneration after injury in aged muscle (Oh et al., 2016) and limits muscle atrophy by decreasing MuRF signaling (Cai et al., 2004). The efficacy of NF- $\mathrm{kB}$ inhibition, using commercially available NSAIDs, on the maintenance of muscle mass and strength in response to exercise has been explored in many clinical studies in elderly patients. A 3-month bout of resistance exercise in elderly patients with knee osteoarthritis, NSAIDs therapy resulted in a mild improvement in muscle strength, however, without hypertrophy (Petersen et al., 2011).
Other studies found that NSAID treatment augmented traininginduced improvement in strength with associated muscle hypertrophy and limited muscle catabolism (Trappe et al., 2011, 2013). Others have instead shown that NSAID supplementation does not improve skeletal muscle strength or function during physical training (Dideriksen et al., 2016). In addition, it should be noted that NSAID therapy is not without its risks in the elderly population. Chronic NSAID use can result in risk of renal failure, cardiovascular events, and gastrointestinal ulceration (Wongrakpanich et al., 2018). As such, the use of NSAIDs during exercise remains a controversial, but potential treatment to augment response to exercise in the aging population. Improved specificity and identifying the correct dosage are, however, requisite to further promotion of this therapy.

\section{Testosterone Therapy}

Testosterone has emerged as another potential supplement to exercise for the elderly population. Multiple studies have demonstrated that testosterone levels decrease with age (Morley et al., 1997; Wang et al., 2009). Testosterone administration to elderly patients increases both muscle mass and maximal voluntary strength in a dose-dependent fashion, possibly by the induction of myogenic gene expression (Bhasin et al., 2001). Despite this assertion, the additional benefits of physiological testosterone replacement in elderly patients remains unclear. A prospective study demonstrated increased upper body strength following testosterone treatment of elderly patients with low to normal serum testosterone, but this treatment did not offer any benefit beyond resistance exercise alone (Hildreth et al., 2013). Others have similarly reported no synergistic or additional benefits of testosterone treatment in PRT (Sullivan et al., 2005). Of note, this is in direct contrast to the benefits of supra-physiological testosterone supplementation with regards to muscle strength and mass in young men, in whom combined treatment with testosterone and exercise was more efficacious than treatment with testosterone or exercise alone (Bhasin et al., 1996). Therefore, it is necessary to consider adjustment of the duration and dosage of testosterone supplementation in exercise regimens for the elderly before conclusion about its efficacy can be drawn. Additionally, like NSAID therapy, testosterone supplementation does not come without potential adverse events, and therefore the clinical efficacy of testosterone for sarcopenia treatment should be carefully evaluated (Basaria et al., 2010).

\section{Growth Hormone/Insulin-Like Growth Factor Supplementation}

The growth hormone (GH) axis is another area that has received attention as a potential supplement for exercise therapy for the elderly. GH is made in the pituitary gland and promotes IGF-1 (insulin growth factor) expression in skeletal muscle (Jorgensen et al., 2006; Velloso, 2008). IGF-1, in turn, stimulates the Akt/mTOR pathway which, as discussed before, promotes muscle anabolism and protein synthesis in response to exercise (Bolster et al., 2003). In elderly patients, GH treatment increases lean body mass and decreases fat-to-muscle ratio from baseline, although it is unclear as to whether this was attributable to increased 
skeletal muscle mass (Rudman et al., 1990, 1991). However, multiple studies have shown that healthy elderly patients do not see any additional benefit in strength or muscle hypertrophy with $\mathrm{GH}$ supplementation as compared to exercise alone, even at 6month follow-up (Taaffe et al., 1994, 1996; Hennessey et al., 2001; Lange et al., 2002), despite confirmation of increased levels of circulating IGF-1. Interestingly, IGF-1 administration in isolation does not increase lean muscle mass. Its effects in combination with exercise, however, have not been independently tested (Friedlander et al., 2001). Separately, losartan, an angiotensin II type I receptor blocker which potentiates IGF-1 activity, failed to improve the anabolic response to physical resistance training (Heisterberg et al., 2018). Despite the integral role of the GH/IGF axis on muscle development or hypertrophy, it does not appear to have a therapeutic benefit in physical training in healthy individuals.

\section{CONCLUSION}

Aging is a complex and heterogenous process. It is, however, uniformly associated with loss of skeletal muscle mass, strength, and function. Resistance exercise in older patients unequivocally results in substantial benefits exemplified by muscle fiber hypertrophy, increased strength, extended independent living, and reduced fall risk (Fragala et al., 2019). Many efforts have focused on improving this response further with nutritional supplements, anti-inflammatory drugs, and anabolic agents. While numerous studies have reported synergistic benefits of combining a supplement with exercise, many others suggest marginal benefits versus exercise alone, especially in elderly

\section{REFERENCES}

Amara, C. E., Shankland, E. G., Jubrias, S. A., Marcinek, D. J., Kushmerick, M. J., and Conley, K. E. (2007). Mild mitochondrial uncoupling impacts cellular aging in human muscles in vivo. Proc. Natl. Acad. Sci. U.S.A. 104, 1057-1062. doi: $10.1073 /$ pnas.0610131104

American College of Sports Medicine Position Stand (1998). Exercise and physical activity for older adults. Med. Sci. Sports Exerc. 30, 992-1008. doi: 10.1249/ 00005768-199806000-00033

Angulo, J., El Assar, M., Álvarez-Bustos, A., and Rodríguez-Mañas, L. (2020). Physical activity and exercise: strategies to manage frailty. Redox Biol. 2020:101513. doi: 10.1016/j.redox.2020.101513

Baker, T. P., Candow, D. G., and Farthing, J. P. (2016). Effect of preexercise creatine ingestion on muscle performance in healthy aging males. J. Strength Cond Res. 30, 1763-1766. doi: 10.1519/jsc.0000000000001254

Barnes, P. J., and Karin, M. (1997). Nuclear Factor-кВ: a pivotal transcription factor in chronic inflammatory diseases. N. Engl. J. Med. 336, 1066-1071. doi: 10.1056/nejm199704103361506

Basaria, S., Coviello, A. D., Travison, T. G., Storer, T. W., Farwell, W. R., Jette, A. M., et al. (2010). Adverse events associated with testosterone administration. N. Engl. J. Med. 363, 109-122. doi: 10.1056/NEJMoa1000485

Baumgartner, R. N., Waters, D. L., Gallagher, D., Morley, J. E., and Garry, P. J. (1999). Predictors of skeletal muscle mass in elderly men and women. Mech. Ageing Dev. 107, 123-136. doi: 10.1016/s0047-6374(98) 00130-4

Behnke, B. J., Ramsey, M. W., Stabley, J. N., Dominguez, J. M., Davis, R. T., McCullough, D. J., et al. (2012). Effects of aging and exercise training on skeletal muscle blood flow and resistance artery morphology. J. Appl. Physiol. 113, 1699-1708. doi: 10.1152/japplphysiol.01025.2012 individuals. Future studies should utilize a standard resistance training regimen, guided by previously published position statements (American College of Sports Medicine Position Stand, 1998), with resistance exercise three times weekly at $30 \mathrm{~min}$ per bout at $60-80 \%$ resistance. Moreover, supplements must be individualized to patients. Elderly patients with low levels of IGF1 or testosterone may benefit from those specific supplements, where as other elderly patients may not. New studies may focus on MIP therapies combining supplements which have demonstrated significant benefit with regards to muscle mass and strength during exercise, such as combining EAAs, Creatinine, Vitamin D, and omega-3 fatty acids. Heterogeneity in the patient population, physical training intensity, and duration of interventions make it difficult to draw generalizable conclusions, but understanding the mechanisms of anabolic resistance and augmenting response to exercise is paramount to maintaining muscle strength and function in aging.

\section{AUTHOR CONTRIBUTIONS}

All authors listed have made a substantial, direct and intellectual contribution to the work, and approved it for publication.

\section{FUNDING}

This work was supported by the National Institute of Aging (K76AG059996 to IS) and a Research and Education Committee Grant (IS) from the Boston Claude D. Pepper Center, which is funded by the National Institute of Aging (P30AG031679).

Bell, K. E., Snijders, T., Zulyniak, M., Kumbhare, D., Parise, G., Chabowski, A., et al. (2017). A whey protein-based multi-ingredient nutritional supplement stimulates gains in lean body mass and strength in healthy older men: a randomized controlled trial. PLoS One 12:e0181387. doi: 10.1371/journal.pone. 0181387

Bhasin, S., Storer, T. W., Berman, N., Callegari, C., Clevenger, B., Phillips, J., et al. (1996). The effects of supraphysiologic doses of testosterone on muscle size and strength in normal men. N. Engl. J. Med. 335, 1-7. doi: 10.1056/ nejm 199607043350101

Bhasin, S., Woodhouse, L., and Storer, T. W. (2001). Proof of the effect of testosterone on skeletal muscle. J. Endocrinol. 170, 27-38. doi: 10.1677/joe.0. 1700027

Biolo, G., Declan Fleming, R. Y., and Wolfe, R. R. (1995). Physiologic hyperinsulinemia stimulates protein synthesis and enhances transport of selected amino acids in human skeletal muscle. J. Clin. Invest. 95, 811-819. doi: $10.1172 /$ jci117731

Bolster, D. R., Kubica, N., Crozier, S. J., Williamson, D. L., Farrell, P. A., Kimball, S. R., et al. (2003). Immediate response of mammalian target of rapamycin (mTOR)-mediated signalling following acute resistance exercise in rat skeletal muscle. J. Physiol. 553, 213-220. doi: 10.1113/jphysiol.2003.047019

Booth, F. W., and Laye, M. J. (2010). The future: genes, physical activity and health. Acta Physiol. 199, 549-556. doi: 10.1111/j.1748-1716.2010.02117.x

Borst, S. E., De Hoyos, D. V., Garzarella, L., Vincent, K., Pollack, B. H., Lowenthal, D. T., et al. (2001). Effects of resistance training on insulin-like growth factor-I and IGF binding proteins. Medand Sci. Sports Exer. 33, 648-653. doi: 10.1097/ 00005768-200104000-00021

Bruunsgaard, H., and Pedersen, B. K. (2003). Age-related inflammatory cytokines and disease. Immunol. Allergy Clin. North Am. 23, 15-39. doi: 10.1016/s08898561(02)00056-5 
Buford, T. W., Anton, S. D., Judge, A. R., Marzetti, E., Wohlgemuth, S. E., Carter, C. S., et al. (2010). Models of accelerated sarcopenia: Critical pieces for solving the puzzle of age-related muscle atrophy. Age Res. Rev. 9, 369-383. doi: 10.1016/ j.arr.2010.04.004

Cai, D., Frantz, J. D., Tawa, N. E. Jr., Melendez, P. A., Oh, B-C., Lidov, H. G. W., et al. (2004). IKKbeta/NF-kappaB activation causes severe muscle wasting in mice. Cell 119, 285-298. doi: 10.1016/j.cell.2004.09.027

Campbell, J. P., and Turner, J. E. (2018). Debunking the myth of exercise-induced immune suppression: redefining the impact of exercise on immunological health across the lifespan. Front. Immunol. 9:648. doi: 10.3389/fimmu.2018. 00648

Campbell, M. J., McComas, A. J., and Petito, F. (1973). Physiological changes in ageing muscles. J. Neurol. Neurosurg. Psych. 36, 174-182. doi: 10.1136/jnnp.36. 2.174

Candow, D. G., Chilibeck, P. D., and Forbes, S. C. (2014). Creatine supplementation and aging musculoskeletal health. Endocrine 45, 354-361. doi: 10.1007/s12020-013-0070-4

Candow, D. G., Forbes, S. C., Chilibeck, P. D., Cornish, S. M., Antonio, J., and Kreider, R. B. (2019). Effectiveness of creatine supplementation on aging muscle and bone: focus on falls prevention and Inflammation. J. Clin. Med. 8:488. doi: $10.3390 /$ jcm 8040488

Chakkalakal, J. V., Jones, K. M., Basson, M. A., and Brack, A. S. (2012). The aged niche disrupts muscle stem cell quiescence. Nature 490, 355-360. doi: 10.1038 /nature 11438

Chami, J., and Candow, D. G. (2019). Effect of creatine supplementation dosing strategies on aging muscle performance. J. Nutr. Health Aging 23, 281-285. doi: 10.1007/s12603-018-1148-8

Chilibeck, P. D., Kaviani, M., Candow, D. G., and Zello, G. A. (2017). Effect of creatine supplementation during resistance training on lean tissue mass and muscular strength in older adults: a meta-analysis. Open Access J. Sports Med. 8, 213-226. doi: 10.2147/oajsm.s123529

Coen, P. M., Jubrias, S. A., Distefano, G., Amati, F., Mackey, D. C., Glynn, N. W., et al. (2013). Skeletal muscle mitochondrial energetics are associated with maximal aerobic capacity and walking speed in older adults. J. Gerontol. A Biol. Sci. Med. Sci. 68, 447-455. doi: 10.1093/gerona/gls196

Conboy, I. M., Conboy, M. J., Smythe, G. M., and Rando, T. A. (2003). Notchmediated restoration of regenerativepotential to aged muscle. Science 302, 1575-1577. doi: 10.1126/science.1087573

Cruz-Jentoft, A. J., Baeyens, J. P., Bauer, J. M., Boirie, Y., Cederholm, T., Landi, F., et al. (2010). Sarcopenia: european consensus on definition and diagnosis: report of the european working group on sarcopenia in older people. Age Ageing 39, 412-423. doi: 10.1093/ageing/afq034

Cuthbertson, D., Smith, K., Babraj, J., Leese, G., Waddel, I. T., Atherton, P., et al. (2005). Anabolic signaling deficits underlie amino acid resistance of wasting, aging muscle. FASEB J. 19, 422-424. doi: 10.1096/fj.04-2640fje

Da Boit, M., Sibson, R., Sivasubramaniam, S., Meakin, J. R., Greig, C. A., Aspden, R. M., et al. (2017). Sex differences in the effect of fish-oil supplementation on the adaptive response to resistance exercise training in older people: a randomized controlled trial. Am. J. Clin. Nutr. 105, 151-158. doi: 10.3945/ajcn. 116.140780

Deane, C. S., Hughes, D. C., Sculthorpe, N., Lewis, M. P., Stewart, C. E., and Sharples, A. P. (2013). Impaired hypertrophy in myoblasts is improved with testosterone administration. J. Ster. Biochem. Mol. Bio. 138, 152-161. doi: 10. 1016/j.jsbmb.2013.05.005

Devries, M. C., and Phillips, S. M. (2014). Creatine supplementation during resistance training in older adults-a meta-analysis. Med. Sci. Sports Exerc. 46, 1194-1203. doi: 10.1249/mss.0000000000000220

Dibble, L. E., Hale, T. F., Marcus, R. L., Droge, J., Gerber, J. P., and LaStayo, P. C. (2006). High-intensity resistance training amplifies muscle hypertrophy and functional gains in persons with Parkinson's disease. Mov. Disord. 21, 1444-1452. doi: 10.1002/mds.20997

Dideriksen, K., Boesen, A. P., Kristiansen, J. F., Magnusson, S. P., Schjerling, P., Holm, L., et al. (2016). Skeletal muscle adaptation to immobilization and subsequent retraining in elderly men: no effect of anti-inflammatory medication. Exp. Gerontol. 82, 8-18. doi: 10.1016/j.exger.2016.05.009

Dideriksen, K. J., Reitelseder, S., Petersen, S. G., Hjort, M., Helmark, I. C., Kjaer, M., et al. (2011). Stimulation of muscle protein synthesis by whey and caseinate ingestion after resistance exercise in elderly individuals. Scand J. Med. Sci. Spor. 21, e372-e383. doi: 10.1111/j.1600-0838.2011.01318.x

Distefano, G., and Goodpaster, B. H. (2018). Effects of exercise and aging on skeletal muscle. Cold Spring Harb Perspect. Med. 8:a029785. doi: 10.1101/cshperspect. a029785

Doherty, T. J. (2003). Invited review: Aging and sarcopenia. J. Appl. Physiol. 95, 1717-1727. doi: 10.1152/japplphysiol.00347.2003

Drummond, M. J., Dreyer, H. C., Pennings, B., Fry, C. S., Dhanani, S., Dillon, E. L., et al. (2008). Skeletal muscle protein anabolic response to resistance exercise and essential amino acids is delayed with aging. J. Appl. Physiol. 104, 1452-1461. doi: 10.1152/japplphysiol.00021.2008

Drummond, M. J., Marcus, R. L., and LaStayo, P. C. (2012). Targeting anabolic impairment in response to resistance exercise in older adults with mobility impairments: potential mechanisms and rehabilitation approaches. J. Aging Res. 2012:486930. doi: 10.1155/2012/486930

Duetz, N. E., Bauer, J., Barazzoni, R., Biolo, G., Boirie, Y., Bosy-Westphal, A., et al. (2014). Protein intake and exercise for optimal muscle function with aging: recommendations from the ESPEN Expert Group. Clin. Nutr. 33, 929-936. doi: 10.1016/j.clnu.2014.04.007

Durham, W. J., Casperson, S. L., Dillon, E. L., Keske, M. A., Paddon-Jones, D., Sanford, A. P., et al. (2010). Age-related anabolic resistance after endurancetype exercise in healthy humans. FASEB J. 24, 4117-4127. doi: 10.1096/fj.09150177

Dutta, C., and Hadley, E. C. (1995). The significance of sarcopenia in old age. J. Gerontol. A Biol. Sci. Med. Sci. 50, 1-4. doi: 10.1093/gerona/50A.Special_ Issue. 1

Ferrando, A. A., Tipton, K. D., Doyle, D., Phillips, S. M., Cortiella, J., and Wolfe, R. R. (1998). Testosterone injection stimulates net protein synthesis but not tissue amino acid transport. Am. J. Physiol. 275, E864-E871. doi: 10.1152/ ajpendo.1998.275.5.E864

Fiatarone, M. A., Marks, E. C., Ryan, N. D., Meredith, C. N., Lipsitz, L. A., and Evans, W. J. (1990). High-intensity strength training in nonagenarians. JAMA 263, 3029-3034. doi: 10.1001/jama.263.22.3029

Fragala, M. S., Cadore, E. L., Dorgo, S., Izquierdo, M., Kraemer, W. J., Peterson Ark, D., et al. (2019). Resistance training for older adults: position statement from the national strength and conditioning association. J. Stren Condition Res. 33, 2019-2052. doi: 10.1519/jsc.0000000000003230

Francaux, M., Demeulder, B., Naslain, D., Fortin, R., Lutz, O., Caty, G., et al. (2016). Aging reduces the activation of the $\mathrm{mTORC} 1$ pathway after resistance exercise and protein intake in human skeletal muscle: potential role of REDD1 and impaired anabolic sensitivity. Nutrients 8:E47. doi: 10.3390/nu8010047

Friedlander, A. L., Butterfield, G. E., Moynihan, S., Grillo, J., Pollack, M., Holloway, L., et al. (2001). One year of insulin-like growth factor I treatment does not affect bone density, body composition, or psychological measures in postmenopausal women. J. Clin. Endocrinol. Metab. 86, 1496-1503. doi: 10.1210/jc.86.4.1496

Frontera, W. R., Meredith, C. N., O’Reilly, K. P., Knuttgen, H. G., and Evans, W. J. (1988). Strength conditioning in older men: skeletal muscle hypertrophy and improved function. J. Appl. Physiol. 64, 1038-1044. doi: 10.1152/jappl.1988.64. 3.1038

Godard, M. P., Williamson, D. L., and Trappe, S. (2002). Oral amino-acid provision does not affect muscle strength or size gains in older men. Med. Sci. Spor. Exer. 34, 1126-1131. doi: 10.1097/00005768-200207000-00012

Gotshalk, L. A., Volek, J. S., Staron, R. S., Denegar, C. R., Hagerman, F. C., and Kraemer, W. J. (2002). Creatine supplementation improves muscular performance in older men. Med. Sci. Sports Exerc. 34, 537-543. doi: 10.1097/ 00005768-200203000-00023

Guillet, C., Prod'homme, M., Balage, M., Gachon, P., Giraudet, C., Morin, L., et al. (2004). Impaired anabolic response of muscle protein synthesis is associated with S6K1 dysregulation in elderly humans. FASEB J. 18, 1586-1587. doi: 10. 1096/fj.03-1341fje

Häkkinen, K., and Pakarinen, A. (1993). Muscle strength and serum testosterone, cortisol and SHBG concentrations in middle-aged and elderly men and women. Acta Physiol. Scand 148, 199-207. doi: 10.1111/j.1748-1716.1993.tb09549.x

Hawkins, V. N., Foster-Schubert, K., Chubak, J., Sorensen, B., Ulrich, C. M., Stancyzk, F. Z., et al. (2008). Effect of exercise on serum sex hormones in men: a 12-month randomized clinical trial. Med. Sci. Sports Exerc. 40, 223-233. doi: $10.1249 / \mathrm{mss} .0 \mathrm{~b} 013 \mathrm{e} 31815 \mathrm{bbba} 9$ 
Hayden, M. S., and Ghosh, S. (2004). Signaling to NF-kappaB. Genes Dev. 18, 2195-2224. doi: 10.1101/gad.1228704

Heisterberg, M. F., Andersen, J. L., Schjerling, P., Lund, A., Dalskov, S., Jønsson, A. O., et al. (2018). Losartan has no additive effect on the response to heavy-resistance exercise in human elderly skeletal muscle. J. Appl. Phys. 125, 1536-1554. doi: 10.1152/japplphysiol.00106.2018

Hennessey, J. V., Chromiak, J. A., DellaVentura, S., Reinert, S. E., Puhl, J., Kiel, D. P., et al. (2001). Growth hormone administration and exercise effects on muscle fiber type and diameter in moderately frail older people. J. Am. Geriatr. Soc. 49, 852-858. doi: 10.1046/j.1532-5415.2001.49173.x

Hepple, R. T., and Rice, C. L. (2016). Innervation and neuromuscular control in ageing skeletal muscle. J. Physiol. 594, 1965-1978. doi: 10.1113/jp270561

Hildreth, K. L., Barry, D. W., Moreau, K. L., Vande Griend, J., Meacham, R. B., Nakamura, T., et al. (2013). Effects of testosterone and progressive resistance exercise in healthy, highly functioning older men with low-normal testosterone levels. J. Clin. Endocrinol. Metab. 98, 1891-1900. doi: 10.1210/jc.2012-3695

Hittel, D. S., Axelson, M., Sarna, N., Shearer, J., Huffman, K. M., and Kraus, W. E. (2010). Myostatin decreases with aerobic exercise and associates with insulin resistance. Med. Sci. Sports Exerc. 42, 2023-2029. doi: 10.1249/mss. 0b013e3181e0b9a8

Holwerda, A. M., Kouw, I. W., Trommelen, J., Halson, S. L., Wodzig, W. K., Verdijk, L. B., et al. (2016). Physical activity performed in the evening increases the overnight muscle protein synthetic response to presleep protein ingestion in older men. J. Nutr. 146, 1307-1314. doi: 10.3945/jn.116.230086

Janssen, I., Shepard, D. S., Katzmarzyk, P. T., and Roubenoff, R. (2004). The healthcare costs of sarcopenia in the United States. J. Am. Geriatr. Soc. 52, 80-85. doi: 10.1111/j.1532-5415.2004.52014.x

Jorgensen, J. O., Jessen, N., Pedersen, S. B., Vestergaard, E., Gormsen, L., Lund, S. A., et al. (2006). GH receptor signalling in skeletal muscle and adipose tissue in human subjects following exposure to an intravenous GH bolus. Am. J. Physiol. Endocrinol. Metab. 291, 899-905. doi: 10.1152/ajpendo.00024.2006

Kang, S. A., Pacold, M. E., Cervantes, C. L., Lim, D., Lou, H. J., Ottina, K., et al. (2013). mTORC1 phosphorylation sites encode their sensitivity to starvation and rapamycin. Science 341:1236566. doi: 10.1126/science. 1236566

Katznelson, L., Finkelstein, J. S., Schoenfeld, D. A., Rosenthal, D. I., Anderson, E. J., and Klibanski, A. (1996). Increase in bone density and lean body mass during testosterone administration in men with acquired hypogonadism. J. Clin. Endocrinol. Metab. 81, 4358-4365. doi: 10.1210/jc.81.12.4358

Kenny, A. M., Prestwood, K. M., Gruman, C. A., Rathier, M., Browner, B., Judge, J. O., et al. (2001). Effects of transdermal testosterone on bone and muscle in older men with low bioavailable testosterone levels. J. Gerontol. A Biol. Sci. Med. Sci. 56, M266-M272. doi: 10.1093/gerona/56.5.M266

Kim, H. K., Suzuki, T., Saiko, K., Yoshida, H., Kobayashi, H., Kato, H., et al. (2012). Effects of exercise and amino acid supplementation on body composition and physical function in community-dwelling elderly Japanese sarcopenic women: a randomized control trial. J. Am. Geriatric. Soc. 60, 16-23. doi: 10.1111/j.15325415.2011.03776.x

Kosek, D. J., Kim, J. S., Petrella, J. K., Cross, J. M., and Bamman, M. M. (2006). Efficacy of 3 days/wk resistance training on myofiber hypertrophy and myogenic mechanisms in young vs. older adults. J. Appl. Physiol. 101, 531-544. doi: 10.1152/japplphysiol.01474.2005

Kouw, I. W., Holwerda, A. M., Trommelen, J., Kramer, I. F., Bastiaanse, J., Halson, S. L., et al. (2017). Protein ingestion before sleep increases overnight muscle protein synthesis rates in healthy older men: a randomized controlled trial. J. Nutr. 147, 2252-2261. doi: 10.3945/jn.117.254532

Kreider, R. B., Kalman, D. S., Antonio, J., Ziegenfuss, T. N., Wildman, R., Collins, R., et al. (2017). International Society of Sports Nutrition position stand: Safety and efficacy of creatine supplementation in exercise, sport, and medicine. J. Int. Soc. Sports Nutr. 14:18. doi: 10.1186/s12970-017-0173-z

Kukuljan, S., Nowson, C. A., Sanders, K., and Daly, R. M. (2009). Effects of resistance exercise and fortified milk on skeletal muscle mass, muscle size, and functional performance in middle-aged and older men: an 18-mo randomized controlled trial. J. Appl. Physiol. 107, 1864-1873. doi: 10.1152/japplphysiol. 00392.2009

Kumar, V., Selby, A., Rankin, D., Patel, R., Atherton, P., Hildebrandt, W., et al. (2009). Age-related differences in the dose-response relationship of muscle protein synthesis to resistance exercise in young and old men. J. Physiol. 587, 211-217. doi: 10.1113/jphysiol.2008.164483
Lange, K. H. W., Andersen, J. L., Beyer, N., Isaksson, F., Larsson, B., Rasmussen, M. H., et al. (2002). GH administration changes myosin heavy chain isoforms in skeletal muscle but does not augment muscle strength or hypertrophy, either alone or combined with resistance exercise training in healthy elderly men. J. Clin. Endocrinol. Metab. 87, 513-523. doi: 10.1210/jcem.87.2.8206

Langley, B., Thomas, M., Bishop, A., Sharma, M., Gilmour, S., and Kambadur, R. (2002). Myostatin inhibits myoblast differentiation by down-regulating MyoD expression. J. Biol. Chem. 277, 49831-49840. doi: 10.1074/jbc.m204291200

Law, T. D., Clark, L. A., and Clark, B. C. (2016). Resistance exercise to prevent and manage sarcopenia and dynapenia. Annu. Rev. Gerontol. Geriatr. 36, 205-228. doi: 10.1891/0198-8794.36.205

Lee, H., Kim, I.-G., Sung, C., Jeon, T.-B., Cho, K., Ha, Y.-C., et al. (2019). Exercise training increases skeletal muscle strength independent of hypertrophy in older adults aged 75 years and older. Geriat Gerontol. 19, 265-270. doi: 10.1111/ggi. 13597

Léger, B., Derave, W., De Bock, K., Hespel, P., and Russell, A. P. (2008). Human sarcopenia reveals an increase in SOCS-3 and myostatin and a reduced efficiency of akt phosphorylation. Rejuv. Res. 11, 163B-175B. doi: 10.1089/rej. 2007.0588

Levis, S., and Gómez-Marín, O. (2017). Vitamin D and physical function in sedentary older men. J. Am. Geriatr. Soc. 65, 323-331. doi: 10.1111/jgs. 14510

Lexell, J. (1995). Human aging, muscle mass, and fiber type composition. J. Gerontol. A Biol. Sci. Med. Sci. 50, 11-16. doi: 10.1093/gerona/50a.special_ issue. 11

Lexell, J., Taylor, C. C., and Sjostrom, M. (1988). What is the cause of the ageing atrophy? Total number, size and proportion of different fiber types studied in whole vastus lateralis muscle from 15- to 83 -year-old men. J. Neurol. Sci. 84, 275-294. doi: 10.1016/0022-510X(88)90132-3

Li, H., Malhotra, S., and Kumar, A. (2008). Nuclear factor-kappa B signaling in skeletal muscle atrophy. J. Mol. Med. (Berl) 86, 1113-1126. doi: 10.1007/s00109008-0373-8

Liu, C. J., and Latham, N. K. (2009). Progressive resistance strength training for improving physical function in older adults. Cochrane Database Syst. Rev. 2009:CD002759. doi: 10.1002/14651858.CD002759.pub2

Lobo, D. M., Tritto, A. C., da Silva, L. R., de Oliveira, P. B., Benatti, F. B., Roschel, H., et al. (2015). Effects of long-term low-dose dietary creatine supplementation in older women. Exp. Gerontol. 70, 97-104. doi: 10.1016/j.exger.2015.07.012

López-Otín, C., Blasco, M. A., Partridge, L., Serrano, M., and Kroemer, G. (2013). The hallmarks of aging. Cell 153, 1194-1217. doi: 10.1016/j.cell.2013.05.039

Losa-Reyna, J., Baltasar-Fernandez, I., Alcazar, J., Navarro-Cruz, R., Garcia-Garcia, F. J., Alegre, L. M., et al. (2019). Effect of a short multicomponent exercise intervention focused on muscle power in frail and pre-frail elderly: a pilot trial. Exp. Gerontol. 115, 114-121. doi: 10.1016/j.exger.2018.11.022

Ly, L. P., Jimenez, M., Zhuang, T. N., Celermajer, D. S., Conway, A. J., and Handelsman, D. J. A. (2001). double-blind, placebo-controlled, randomized clinical trial of transdermal dihydrotestosterone gel on muscular strength, mobility, and quality of life in older men with partial androgen deficiency. J. Clin. Endocrinol. Metab. 86, 4078-4088. doi: 10.1210/jcem.86.9. 7821

MacLaughlin, J., and Holick, M. F. (1985). Aging decreases the capacity of human skin to produce vitamin D3. J. Clin. Invest. 76, 1536-1538. doi: 10.1172/ jci112134

Marcus, R. L., Addison, O., Kidde, J. P., Dibble, L. E., and Lastayo, P. C. (2010). Skeletal muscle fat infiltration: impact of age, inactivity, and exercise. J. Nutr. Health Aging 14, 362-366. doi: 10.1007/s12603-010-0081-2

Markofski, M. M., Dickinson, J. M., Drummond, M. J., Fry, C. S., Fujita, S., Gundermann, D. M., et al. (2015). Effect of age on basal muscle protein synthesis and mTORC1 signaling in a large cohort of young and older men and women. Exp. Gerontol. 65, 1-7. doi: 10.1016/j.exger.2015.02.015

Martínez-Velilla, N., Casas-Herrero, A., Zambom-Ferraresi, F., Sáez de Asteasu, M. L., Lucia, A., Galbete, A., et al. (2019). Effect of exercise intervention on functional decline in very elderly patients during acute hospitalization. JAMA Intern. Med. 179, 28-36.

Melton, L. J. I. I. I., Khosla, S., Crowson, C. S., O’Connor, M. K., O’Fallon, W. M., and Riggs, B. L. (2000). Epidemiology of sarcopenia. J. Am. Geriatr. Soc. 48, 625-630. doi: 10.1111/j.1532-5415.2000.tb04719.x

Messi, M. L., Li, T., Wang, Z. M., Marsh, A. P., Nicklas, B., and Delbono, O. (2016). Resistance training enhances skeletal muscle innervation without modifying 
the number of satellite cells or their myofiber association in obese older adults. J. Gerontol. A Biol. Sci. Med. Sci. 71, 1273-1280. doi: 10.1093/gerona/glv176

Moreira-Pfrimer, L. D., Pedrosa, M. A., Teixeira, L., and Lazaretti-Castro, M. (2009). Treatment of vitamin D deficiency increases lower limb muscle strength in institutionalized older people independently of regular physical activity: a randomized double-blind controlled trial. Ann. Nutr. Metab. 54, 291-300. doi: $10.1159 / 000235874$

Morley, J. E., Kaiser, F. E., Perry, H. M., Patrick, P., Morley, P. M., Stauber, P. M., et al. (1997). Longitudinal changes in testosterone, luteinizing hormone, and follicle-stimulating hormone in healthy older men. Metab 46, 410-413. doi: 10.1016/s0026-0495(97)90057-3

Nieman, D. C., Davis, J. M., Henson, D. A., Walberg-Rankin, J., Shute, M., Dumke, C. L., et al. (2003). Carbohydrate ingestion influences skeletal muscle cytokine mRNA and plasma cytokine levels after a 3-h run. J. Appl. Physiol. 94, 1917-1925. doi: 10.1152/japplphysiol.01130.2002

O’Bryan, K. R., Coffey, V. G., Phillips, S. M., Cox, G. R., et al. (2020). Do multiingredient protein supplements augment resistance training-induced gains in skeletal muscle mass and strength? A systematic review and meta-analysis of 35 trials. Br. J. Sports Med. 54, 573-581. doi: 10.1136/bjsports-2018-099889

Ogawa, T., Spina, R. J., Martin, W. H., Kohrt, W. M., Schechtman, K. B., Holloszy, J. O., et al. (1992). Effects of aging, sex, and physical training on cardiovascular responses to exercise. Circulation 86, 494-503. doi: 10.1161/01.cir.86.2.494

Oh, J., Sinha, I., Tan, K. Y., Rosner, B., Dreyfuss, J. M., Gjata, O., et al. (2016). Age-associated NF- $\mathrm{B}$ signaling in myofibers alters the satellite cell niche and re-strains muscle stem cell function. Aging (Albany N. Y.) 8, 2871-2896. doi: 10.18632/aging.101098

Oktaviana, J., Zanker, J., Vogrin, S., and Duque, G. (2019). The Effect of $\beta$ Hydroxy- $\beta$-Methylbutyrate (HMB) on sarcopenia and functional frailty in older persons: a systematic review. J. Nutr. Health Aging 23, 145-150. doi: 10.1007/s12603-018-1153-y

Pahor, M., Guralnik, J. M., Ambrosius, W. T., Blair, S., Bonds, D. E., Church, T. S., et al. (2014). Effect of structured physical activity on prevention of major mobility disability in older adults: the LIFE study randomized clinical trial. JAMA 311, 2387-2396. doi: 10.1001/jama.2014.5616

Pallafacchina, G., Calabria, E., Serrano, A. L., Kalhovde, J. M., and Schiaffino, S. A. (2002). protein kinase B-dependent and rapamycin-sensitive pathway controls skeletal muscle growth but not fiber type specification. Proc. Natl. Acad. Sci. U.S.A. 99, 9213-9218. doi: 10.1073/pnas.142166599

Parise, G., Mihic, S., MacLennan, D., Yarasheski, K. E., and Tarnopolsky, M. A. (2001). Effects of acute creatine monohydrate supplementation on leucine kinetics and mixed-muscle protein synthesis. J. Appl. Physiol. 91, 1041-1047. doi: 10.1152 jappl.2001.91.3.1041

Pedersen, M., Bruunsgaard, H., Weis, N., Hendel, H., Andreassen, B., Eldrup, E., et al. (2003). Circulating levels of TNF-alpha and IL-6-relation to truncal fat mass and muscle mass in healthy elderly individuals and in patients with type-2 diabetes. Mech. Ageing Dev. 124, 495-502. doi: 10.1016/s0047-6374(03)00027-7

Pennings, B., Koopman, R., Beelen, M., Senden, J. M. G., Saris, W. H. M., and Van Loon, L. J. C. (2011). Exercising before protein intake allows for greater use of dietary protein-derived amino acids for de novo muscle protein synthesis in both young and elderly men. Am. J. Clin. Nutr. 93, 322-331. doi: 10.3945/ajcn. 2010.29649

Petersen, K. F., Morino, K., Alves, T. C., Kibbey, R. G., Dufour, S., Sono, S., et al. (2015). Effect of aging on muscle mitochondrial substrate utilization in humans. Proc. Natl. Acad. Sci. U.S.A. 112, 11330-11334. doi: 10.1073/pnas. 1514844112

Petersen, S. G., Beyer, N., Hansen, M., Holm, L., Aagaard, P., Mackey, A. L., et al. (2011). Nonsteroidal anti-inflammatory drug or glucosamine reduced pain and improved muscle strength with resistance training in a randomized controlled trial of knee osteoarthritis patients. Arch. Phys. Med. Rehabil. 92, 1185-1193. doi: 10.1016/j.apmr.2011.03.009

Peterson, M. D., Sen, A., and Gordon, P. M. (2011). Influence of resistance exercise on lean body mass in aging adults: a meta-analysis. Med. Sci. Sports Exerc. 43, 249-258. doi: 10.1249/mss.0b013e3181eb6265

Pfeifer, M., Begerow, B., Minne, H. W., Suppan, K., Fahrleitner-Pammer, A., and Dobnig, H. (2009). Effects of a long-term vitamin D and calcium supplementation on falls and parameters of muscle function in communitydwelling older individuals. Osteoporos Int. 20, 315-322. doi: 10.1007/s00198008-0662-7
Phillips, B. E., Williams, J. P., Greenhaff, P. L., Smith, K., and Atherton, P. J. (2017). Physiological adaptations to resistance exercise as a function of age. JCI Insight 2:e95581. doi: 10.1172/jci.insight.95581

Piasecki, M., Ireland, A., Coulson, J., Stashuk, D. W., Hamilton-Wright, A., Swiecicka, A., et al. (2016). Motor unit number estimates and neuromuscular transmission in the tibialis anterior of master athletes: evidence that athletic older people are not spared from age-related motor unit remodeling. Physiol. Rep. 4:e12987. doi: 10.14814/phy2.12987

Power, G. A., Dalton, B. H., Behm, D. G., Doherty, T. J., Vandervoort, A. A., and Rice, C. L. (2012). Motor unit survival in lifelong runners is muscle dependent. Med. Sci. Sport Exerc. 44, 1235-1242. doi: 10.1249/mss.0b013e318249953c

Powers, M. L., and Florini, J. R. A. (1975). direct effect of testosterone on muscle cells in tissue culture. Endocrinol 97, 1043-1047. doi: 10.1210/endo-97-4-1043

Raj, I. S., Bird, S. R., and Shield, A. J. (2010). Aging and the force-velocity relationship of muscles. Exp. Gerentol. 45, 81-90. doi: 10.1016/j.exger.2009.10. 013

Rantanen, T., Guralnik, J. M., Foley, D., Masaki, K., Leveille, S., Curb, J. D., et al. (1999). Midlife handgrip strength as a predictor of old age disability. JAMA 281, 558-560. doi: 10.1001/jama.281.6.558

Rasmussen, B. B., Fujita, S., Wolfe, R. R., Mittendorfer, B., Roy, M., Rowe, V. L., et al. (2006). Insulin resistance of muscle protein metabolism in aging. FASEB J. 20, 768-769. doi: 10.1096/fj.05-4607fje

Rivas, D. A., Morris, E. P., Haran, P. H., Pasha, E. P., Morais Mda, S., Dolnikowski, G. G., et al. (2012). Increased ceramide content and NFKB signaling may contribute to the attenuation of anabolic signaling after resistance exercise in aged males. J. Appl. Physiol. 113, 1727-1736. doi: 10.1152/japplphysiol.00412. 2012

Rodacki, C. L., Rodacki, A. L., Pereira, G., Naliwaiko, K., Coelho, I., Pequito, D., et al. (2012). Fish-oil supplementation enhances the effects of strength training in elderly women. Am. J. Clin. Nutr. 95, 428-436. doi: 10.3945/ajcn.111.021915

Rodriguez-Mañas, L., Laosa, O., Vellas, B., Paolisso, G., Topinkova, E., Oliva-Moreno, J., et al. (2019). MID-Frail consortium. effectiveness of a multimodal intervention in functionally impaired older people with type 2 diabetes mellitus. J. Cachexia Sarcopenia Muscle 10, 721-733. doi: 10.1002/jcsm. 12432

Rosenberg, I. (1989). Summary comments: epidemiological and methodological problems in determining nutritional status of older persons. Am. J. Clin. Nutr. 50, 1231-1233. doi: 10.1093/ajcn/50.5.1231

Rudman, D., Feller, A. G., Cohn, L., Shetty, K. R., Rudman, I. W., and Draper, M. W. (1991). Effects of human growth hormone on body composition in elderly men. Horm. Res. Suppl. 1, 73-81. doi: 10.1159/000182193

Rudman, D., Feller, A. G., Nagraj, H. S., Gergans, G. A., Lalitha, P. Y., Goldberg, A. F., et al. (1990). Effects of human growth hormone in men over 60 years old. N. Engl. J. Med. 323, 1-6. doi: 10.1056/nejm199007053230101

Safdar, A., Yardley, N. J., Snow, R., Melov, S., and Tarnopolsky, M. A. (2008). Global and targeted gene expression and protein content in skeletal muscle of young men following short-term creatine monohydrate supplementation. Physiol. Genomics 32, 219-228. doi: 10.1152/physiolgenomics.00157.2007

Sartori, R., Milan, G., Patron, M., Mammucari, C., Blaauw, B., Abraham, R., et al. (2009). Smad2 and 3 transcription factors control muscle mass in adulthood. Am. J. Physiol. Cell Physiol. 296, C1248-C1257. doi: 10.1152/ajpcell.00104.2009

Sculthorpe, N., Solomon, A. M., Sinanan, A. C., Bouloux, P. M., Grace, F., and Lewis, M. P. (2012). Androgens affect myogenesis in vitro and increase local IGF-1 expression. Med. Sci. Sports Exerc. 44, 610-615. doi: 10.1249/mss. 0b013e318237c5c0

Sestili, P., Martinelli, C., Colombo, E., Barbieri, E., Potenza, L., Sartini, S., et al. (2011). Creatine as an antioxidant. Amino Acids 40, 1385-1396. doi: 10.1007/ s00726-011-0875-5

Sharples, A. P., Al-Shanti, N., Hughes, D. C., Lewis, M. P., and Stewart, C. E. (2013). The role of insulin-like-growth factor binding protein 2 (IGFBP2) and phosphatase and tensin homologue (PTEN) in the regulation of myoblast differentiation and hypertrophy. Growth Hor. IGF Res. 23, 53-61. doi: 10.1016/ j.ghir.2013.03.004

Shea, M. K., Fielding, R. A., and Dawson-Hughes, B. (2019). The effect of vitamin $\mathrm{D}$ supplementation on lower-extremity power and function in older adults: a randomized controlled trial. Am. J. Clin. Nutr. 109, 369-379. doi: 10.1093/ajcn/ nqy 290 
Shibaguchi, T., Maeoka, T., Yoshihara, T., Naito, H., Goto, K., Yoshioka, T., et al. (2018). Age-related changes in myostatin expression in rat skeletal muscles. J. Phys. Fit. Sports Med. 7, 221-227. doi: 10.7600/jpfsm.7.221

Smith, G. I., Atherton, P., Reeds, D. N., Mohammed, B. S., Rankin, D., Rennie, M. J., et al. (2011). Dietary omega-3 fatty acid supplementation increases the rate of muscle protein synthesis in older adults: a randomized controlled trial. Am. J. Clin. Nutr. 93, 402-412. doi: 10.3945/ajcn.110.005611

Snijders, T., Res, P. T., Smeets, J. S., Kramer, I. F., Bastiaanse, J., Halson, S. L., et al. (2015). Protein ingestion before sleep increases muscle mass and strength gains during prolonged resistance-type exercise training in healthy young men. J. Nutr. 145, 1178-1184. doi: 10.3945/jn.114.208371

Song, Z., Moore, D. R., Hodson, N., Ward, C., Dent, J. R., O'Leary, M. F., et al. (2017). Resistance exercise initiates mechanistic target of rapamycin (mTOR) translocation and protein complex co-localisation in human skeletal muscle. Sci. Rep. 7:5028. doi: 10.1038/s41598-017-05483-x

Steffl, M., Bohannon, R. W., Sontakova, L., Tufano, J. J., Shiells, K., and Holmerova, I. (2017). Relationship between sarcopenia and physical activity in older people: a systematic review and meta-analysis. Clin. Interven. Aging 12, 835-845. doi: 10.2147/cia.s132940

Studenski, S. A., Peters, K. W., Alley, D. E., Cawthon, P. M., McLean, R. R., Harris, T. B., et al. (2014). The FNIH sarcopenia project: rationale, study description, conference recommendations, and final estimates. J. Gerontol. A Biol. Sci. Med. Sci. 69, 547-558. doi: 10.1093/gerona/glu010

Suetta, C., Frandsen, U., Mackey, A. L., Jensen, L., Hvid, L. G., Bayer, M. L., et al. (2013). Aging is associated with diminished muscle regrowth and myogenic precursor cell expansion early after immobility-induced atrophy in human skeletal muscle. J. Physiol. 591, 3789-3804. doi: 10.1113/jphysiol.2013.257121

Sullivan, D. H., Roberson, P. K., Johnson, L. E., Bishara, O., Evans, W. J., Smith, E. S., et al. (2005). Effects of muscle strength training and testosterone in frail elderly males. Med. Sci. Sports Exerc. 37, 1664-1672. doi: 10.1249/01.mss. $0000181840.54860 .8 \mathrm{~b}$

Taaffe, D. R., Jin, I. H., Vu, T. H., Hoffman, A. R., and Marcus, R. (1996). Lack of effect of recombinant human growth hormone $(\mathrm{GH})$ on muscle morphology and $\mathrm{GH}$-insulin-like growth factor expression in resistance-trained elderly men. J. Clin. Endocrinol. Metab. 81, 421-425. doi: 10.1210/jc.81.1.421

Taaffe, D. R., Pruitt, L., Reim, J., Hintz, R. L., Butterfield, G., Hoffman, A. R., et al. (1994). Effect of recombinant human growth hormone on the muscle strength response to resistance exercise in elderly men. J. Clin. Endocrinol. Metab. 79, 1361-1366. doi: 10.1210/jc.79.5.1361

Thaloor, D., Miller, K. J., Gephart, J., Mitchell, P. O., and Pavlath, G. K. (1999). Systemic administration of the NF-kappaB inhibitor curcumin stimulates muscle regeneration after traumatic injury. Am. J. Physiol. 277, C320-C329. doi: 10.1152/ajpcell.1999.277.2.C320

Thompson, L. V. (2002). Skeletal muscle adaptations with age, inactivity, and therapeutic exercise. J. Orthop Sports Phys. Ther. 32, 44-57. doi: 10.2519/jospt. 2002.32.2.44

Trappe, T. A., Carroll, C. C., Dickinson, J. M., LeMoine, J. K., Haus, J. M., Sullivan, B. E., et al. (2011). Influence of acetaminophen and ibuprofen on skeletal muscle adaptations to resistance exercise in older adults. Am. J. Physiol. Reg. Integr. Comp. Physiol. 300, 655-662. doi: 10.1152/ajpregu.00611.2010

Trappe, T. A., Standley, R. A., Jemiolo, B., Carroll, C. C., and Trappe, S. W. (2013). Prostaglandin and myokine involvement in the cyclooxygenase inhibiting drug enhancement of skeletal muscle adaptations to resistance exercise in older adults. Am. J. Physiol. Regul. Integr. Comp. Physiol. 304, 198-205. doi: 10.1152/ ajpregu.00245.2012

Trendelenburg, A. U., Meyer, A., Rohner, D., Boyle, J., Hatakeyama, S., and Glass, D. J. (2009). Myostatin reduces Akt/TORC1/p70S6K signaling, inhibiting myoblast differentiation and myotube size. Am. J. Physiol. Cell Physiol. 296, C1258-C1270. doi: 10.1152/ajpcell.00105.2009

Uusi, U.-R. K., Patil, R., Karinkanta, S., Kannus, P., Tokola, K., Lamberg-Allardt, C., et al. (2015). Exercise and vitamin D in fall prevention among older women: a randomized clinical trial. JAMA Intern. Med. 175, 703-711. doi: 10.1001/ jamainternmed.2015.0225

Velloso, C. P. (2008). Regulation of muscle mass by growth hormone and IGF-I. Br. J. Pharmacol. 154, 557-568. doi: 10.1038/bjp.2008.153

Verdijk, L. B., Jonkers, R. A. M., Gleeson, B. G., Beelen, M., Meijer, K., Savelberg, H. H., et al. (2009). Protein supplementation before and after exercise does not further augment skeletal muscle hypertrophy after resistance training in elderly men. Am. J. Clin. Nutr. 89, 608-616. doi: 10.3945/ajcn.2008.26626

Visser, M., Deeg, D. J., and Lips, P. (2003). Longitudinal aging study amsterdam. low vitamin $d$ and high parathyroid hormone levels as determinants of loss of muscle strength and muscle mass (sarcopenia): the longitudinal aging study amsterdam. J. Clin. Endocrinol. Metab. 88, 5766-5772. doi: 10.1210/jc.2003030604

Volpi, E., Nazemi, R., and Fujita, S. (2004). Muscle tissue changes with aging. Curr. Opin. Clin. Nutr. Metab. Care 7, 405-410. doi: 10.1097/01.mco.0000134362. 76653.b2

Wall, B. T., Gorissen, S. H., Pennings, B., Koopman, R., Groen, B. B., Verdijk, L. B., et al. (2015). Aging is accompanied by a blunted muscle protein synthetic response to protein ingestion. PLoS One 10:e0140903. doi: 10.1371/journal. pone. 0140903

Wang, C., Nieschlag, E., Swerdloff, R., Behre, H. M., Hellstrom, W. J., Gooren, L. J., et al. (2009). Investigation, treatment and monitoring of late-onset hypogonadism in males. Int. J. Androl. 32, 1-10. doi: 10.1111/j.1365-2605.2008. 00924.x

Welle, S., Totterman, S., and Thornton, C. (1996). Effect of age on muscle hypertrophy induced by resistance training. J. Gerontol. A. Biol. Sci. Med. Sci. 51, M270-M275. doi: 10.1093/gerona/51A.6.M270

Wilkinson, D. J., Piasecki, M., and Atherton, P. J. (2018). The age-related loss of skeletal muscle mass and function: measurement and physiology of muscle fibre atrophy and muscle fibre loss in humans. Ageing Res. Rev. 47, 123-132. doi: 10.1016/j.arr.2018.07.005

Wolfson, L., Judge, J., Whipple, R., and King, M. (1995). Strength is a major factor in balance, gait, and the occurrence of falls. J. Gerontol. A Biol. Sci. Med. Sci. 50, 64-67. doi: 10.1093/gerona/50a.special_issue.64

Wongrakpanich, S., Wongrakpanich, A., Melhado, K., and Rangaswami, J. A. (2018). Comprehensive review of non-steroidal anti-inflammatory drug use in the elderly. Aging Dis. 9, 143-150. doi: 10.14336/AD.2017.0306

Yamamoto, Y., and Gaynor, R. B. (2001). Therapeutic potential of inhibition of the NF-kappaB pathway in the treatment of inflammation and cancer. J. Clin. Invest. 107, 35-142. doi: 10.1172/JCI11914

Yang, W., Zhang, Y., Li, Y., Wu, Z., and Zhu, D. (2007). Myostatin induces cyclin D1 degradation to cause cell cycle arrest through a phosphatidylinositol 3kinase/AKT/GSK-3 $\beta$ pathway and is antagonized by insulin-like growth factor 1. J. Biol. Chem. 282, 3799-3808. doi: 10.1074/jbc.m610185200

Yoon, M. S. (2017). mTOR as a key regulator in maintaining skeletal muscle mass. Front. Physiol. 17:788. doi: 10.3389/fphys.2017.00788

Yu, R., Tong, C., Ho, F., and Woo, J. (2019). Effects of a multicomponent frailty prevention program in prefrail community-dwelling older persons: a randomized controlled trial. J. Am. Med. Dir. Assoc. 19, 3064030641 .

Conflict of Interest: The authors declare that the research was conducted in the absence of any commercial or financial relationships that could be construed as a potential conflict of interest.

Copyright (C) 2020 Endo, Nourmahnad and Sinha. This is an open-access article distributed under the terms of the Creative Commons Attribution License (CC BY). The use, distribution or reproduction in other forums is permitted, provided the original author(s) and the copyright owner(s) are credited and that the original publication in this journal is cited, in accordance with accepted academic practice. No use, distribution or reproduction is permitted which does not comply with these terms. 